\title{
Visualizing Pharmacological Activities of Antidepressants: A Novel Approach
}

\author{
Hieronymus J. Derijks ${ }^{1,2}$, Eibert R. Heerdink ${ }^{1}$, Rob Janknegt ${ }^{2}$, Fred H.P. De Koning ${ }^{1,3}$, \\ Berend Olivier ${ }^{*}, 4$, Anton J.M. Loonen ${ }^{5}$ and Antoine C.G. Egberts ${ }^{1,6}$
}

\author{
${ }^{I}$ Department of Pharmacoepidemiology and Pharmacotherapy, Utrecht Institute for Pharmaceutical Sciences (UIPS), \\ Utrecht University, P.O. Box 80082, 3508 TB Utrecht, The Netherlands \\ ${ }^{2}$ Department of Clinical Pharmacy, Orbis Medical Center, P.O. Box 5500, 6130 MB, Sittard, The Netherlands \\ ${ }^{3}$ Kring Apotheken Nederland, P.O. Box 210, 5201 AE Den Bosch, The Netherlands \\ ${ }^{4}$ Division of Psychopharmacology, Utrecht Institute for Pharmaceutical Sciences (UIPS), Utrecht University, P.O. Box \\ 80082, 3508 TB Utrecht, The Netherlands \\ ${ }^{5}$ Department of Pharmacotherapy and Pharmaceutical Care, Pharmacy and Pharmaceutical Sciences - Faculty of \\ Mathematics and Natural Sciences, Groningen University, Antonius Deusinglaan 1, 9713 AV, Groningen, The \\ Netherlands \\ ${ }^{6}$ Department of Clinical Pharmacy, University Medical Center Utrecht, P.O. Box 85500, 3508 GA Utrecht, The \\ Netherlands
}

\begin{abstract}
Antidepressants have different receptor binding profiles, which are related to therapeutic action and adverse drug reactions. We constructed a model to classify antidepressants on the basis of their binding properties of most common transporter- and receptor sites. Receptor binding was quantified by calculating receptor occupancy for the 5-HT (serotonin) reuptake transporter, norepinephrinic reuptake transporter, 5- $\mathrm{HT}_{2 \mathrm{C}}$-receptor, $\mathrm{M}_{3}$-receptor, $\mathrm{H}_{1}$-receptor and $\alpha_{1}$ receptor. To identify groups of antidepressants that show similar patterns of receptor occupancy for different receptors, hierarchical cluster analysis (HCA) and principle component analysis (PCA) were used. In addition, to visualize (a)symmetry between binding profiles of antidepressants, radar plots were constructed. On the basis of both analyses, four clusters of antidepressants which exert similar pharmacological properties were identified. Potentially, this model could be a helpful tool in medical practice and may be used as a prediction model for adverse effects of drugs entering the market.
\end{abstract}

\section{INTRODUCTION}

Since 1958, more than 20 antidepressants have reached the market and they have proven to be effective in the treatment of depression and other psychiatric disorders. It still remains to be elucidated what the mechanism is behind these therapeutic effects [1]. All currently approved antidepressants elevate central monoamines in the brain (particularly serotonin and norepinephrine), although important pharmacological differences exists in the way antidepressants exert these effects. Meta-analyses have revealed that modern antidepressants overall are not more efficacious and act not more rapidly than the first generation agents such as imipramine and clomipramine [2-5]. Besides, in treatment-resistant depression, intraclass switching from one serotonergic reuptake inhibitor (SSRI) to another has proven to be effective in 40$70 \%$ of the patients [6] which is hard to explain from a pharmacological point of view. In contrast, much more is known about the relation between adverse drug reactions and

*Address correspondence to this author at the Division of Psychopharmacology, Utrecht Institute for Pharmaceutical Sciences, Faculty of Science, Utrecht University, P.O. Box 80-082, 3508 TB, Utrecht, The Netherlands; Tel: +31 302533529; Fax: +31 302531599; E-mail: B.Olivier@uu.nl the pharmacological mechanisms of antidepressants [7]. Two major groups of adverse drug reactions can be recognized: type $A$ and $B$ effects. Type A adverse drug reactions are adverse effects related to the pharmacological actions of the drug. Type B adverse drug reactions, refer to the phenomenon that a medicine is well tolerated by the (vast) majority of users, but occasionally elicits a patient specific reaction to the drug not related to pharmacology [8]. It has been shown that important differences exist between antidepressants with respect to the nature of adverse drug reactions and that these tolerability and safety aspects are important for tailoring an antidepressant to the individual patient as well as for adherence of the patient to antidepressant therapy.

Traditionally, antidepressants are put into the market and classified on the basis of a) their molecular structure and/or b) the way they interfere with the serotonergic and norepinephrinic neurotransmitter systems. Five commonly defined categories are: 1) tricyclic antidepressants (TCAs), 2) selective serotonin reuptake inhibitors (SSRIs), 3) dual serotonin and norepinephrine reuptake inhibitors (SNRIs) 4) serotonin2 antagonist/reuptake inhibitors (SARIs) and 5) norepinephrinic and specific serotonergic antidepressants (NaSSAs). From a pharmacological point of view this classification can 
be quite confusing. For example, clomipramine is classified as a TCA but pharmacologically shows very much similarity with SSRIs. A pharmacodynamic system of classification can easily accommodate new agents as they become available. For example, it is known that it is difficult to translate results about the safety of drugs from clinical trial data into clinical practice, because trials are conducted in relatively small and highly selected groups of patients. Furthermore, most adverse drug reactions are discovered during extended use after approval. A model which identifies antidepressants based on their pharmacological binding properties may be beneficial in the better assessment and understanding of the adverse drug reaction profile of novel agents. Furthermore, for many clinicians, it provides a rational basis for sequential treatment selection, particularly in those cases when a patient has experienced ADRs. Finally, a pharmacodynamic classification system also may be used in pharmacovigilance in the search for high risk antidepressants for specific adverse drugs reactions. This system may help us to unravel the mechanism behind these adverse drug reactions.

Thus, for a better understanding of receptor-mediated pharmacological action, we constructed a multivariate model to classify antidepressants on the basis of their binding properties of most common transporter- and receptor sites.

\section{MATERIALS AND METHODS}

Receptor binding was quantified by calculating receptor/transporter occupancy (hereafter: receptor occupancy) for the 5-HT (5-hydroxytryptamine) reuptake transporter, norepinephrine reuptake transporter, muscarine $\mathrm{M}_{3}$-receptor, histamine $\mathrm{H}_{1}$-receptor, alpha $\alpha_{1}$-receptor and $5-\mathrm{HT}_{2 \mathrm{c}}$-receptor. The 5-HT reuptake transporter and norepinephrine reuptake transporter are the primary transporters responsible for central monoamines elevation and the muscarine $\mathrm{M}_{3}$-receptor, histamine $\mathrm{H}_{1}$-receptor, alpha $\alpha_{1}$-receptor and 5- $\mathrm{HT}_{2 \mathrm{c}}$-receptor are pharmacological related to common type A adverse drug reactions of antidepressants. Receptor occupancy expresses the magnitude of the binding of a drug to the receptor site at mean steady state plasma concentration. To identify clusters of antidepressants with a similar binding profile, hierarchical cluster analysis and principle component analysis (PCA) were used [9]. Subsequently, to visualize (a)symmetry between binding profiles of antidepressants, radar plots were constructed.

\section{Receptor Occupancy Model}

\section{Pharmacokinetic Parameters}

The mean steady state plasma concentration $\left(\mathrm{C}_{\mathrm{ss}}\right)$ of antidepressants was obtained by calculating the average value of the lower limit $\left(\mathrm{C}_{\min }\right)$ and upper limit $\left(\mathrm{C}_{\max }\right)$ of the therapeutic window using the following equation:

$\mathrm{C}_{\mathrm{ss}}=\left(\mathrm{C}_{\max }+\mathrm{C}_{\min }\right) / 2$

The mean unbound plasma concentration $\left(\mathrm{C}_{\mathrm{u}}\right)$ was calculated by multiplying $\mathrm{C}_{\mathrm{ss}}$ by the plasma unbound fraction $\left(\mathrm{f}_{\mathrm{u}}\right)$ :

$\mathrm{C}_{\mathrm{u}}=\mathrm{C}_{\mathrm{ss}} * \mathrm{f}_{\mathrm{u}}$

$\mathrm{C}_{\max }, \mathrm{C}_{\min }$ and fu were obtained from reference lists used in hospitals in The Netherlands for Therapeutic Drug Monitoring (TDM) [10, 11]. For bupropion, duloxetine and reboxetine a therapeutic window was not available. The mean free steady state plasma concentrations for these compounds were calculated by multiplying the plasma unbound fraction $\left(f_{u}\right)$ by the bioavailability $(F)$ and the dose of the drug $\left(D_{0}\right)$ divided by the multiplication of volume of distribution $\left(\mathrm{V}_{\mathrm{d}}\right)$, elimination constant $(\mathrm{k})$ and dosing interval $(\tau)$.

$\mathrm{C}_{\mathrm{u}}=\left(\mathrm{f}_{\mathrm{u}} * \mathrm{~F} * \mathrm{D}_{0}\right) /\left(\mathrm{V}_{\mathrm{d}} * \mathrm{k} * \tau\right)$

\section{Inhibition Constants of Antidepressants}

The inhibition constant $\left(\mathrm{K}_{\mathrm{i}}\right)$ is a measure of the binding affinity of a ligand (antidepressant) for its receptor. $\mathrm{K}_{\mathrm{i}}$ is the concentration of the ligand in which the receptor is occupied for $50 \%$ by the ligand. $\mathrm{K}_{\mathrm{i}}$ 's for all antidepressants were obtained from the Psychoactive Drug Screening Program (PDSP) $\mathrm{K}_{\mathrm{i}}$ database [12] and literature [7, 13-42]. The PDSP $\mathrm{K}_{\mathrm{i}}$ database serves as a data warehouse for published and internally-derived $K_{i}$, or affinity, values for a large number of drugs and drug candidates at an expanding number of $\mathrm{G}$ protein coupled receptors, ion channels, transporters and enzymes. Most of the $\mathrm{K}_{\mathrm{i}}$-values were obtained from experiments with cloned human receptor cell lines, but also human receptors from brain tissue, (frontal) cortex, tissue, choroids plexus tissue, striatum tissue, cortical membranes and platelets were used. When we found more than one $\mathrm{K}_{\mathrm{i}}$-value for a specific antidepressant-human receptor interaction we took an average value of the $K_{i}$ s. When no $K_{i}$-value for a specific antidepressant-human receptor interaction was available, we took a $\mathrm{K}_{\mathrm{i}}$-value for a specific antidepressant-animal receptor interaction. If $\mathrm{K}_{\mathrm{i}}$-values exceeded $10,000 \mathrm{nM}$ a value of $10,000 \mathrm{nM}$ was assumed. Higher values will not contribute substantially to receptor occupancy at mean steady state plasma concentration of antidepressants.

\section{Quantitative Prediction of Pharmacological Action Based on Average Pharmacokinetic Parameters}

The extent of pharmacological action by antidepressants at steady-state concentrations was predicted by using the following procedure. Receptor occupancy $(\Phi)$ for different receptors, an index of the extent of different pharmacological actions, can be expressed in terms of unbound drug concentration around the receptor $\left(\mathrm{C}_{\mathrm{d}}\right)$ and the $\mathrm{K}_{\mathrm{i}}$ of each antidepressant for all different receptors, according to the following equation:

$$
\Phi=\left(\mathrm{C}_{\mathrm{d}} /\left(\mathrm{K}_{\mathrm{i}}+\mathrm{C}_{\mathrm{d}}\right)\right) * 100 \%
$$

(see appendix 1 for derivation)

The receptor occupancy values at steady state were calculated by assuming that $C_{d}$ in equation 4 is equal to $C_{u}$ in equation 2 and substituting equation 2 in equation 4 . This assumption is true for well perfused peripheral tissue and organs. Passage of the blood brain barrier is relatively easy for lipophilic agents like antidepressants. However, not concerned with hypothetical influence of p-glycoprotein, binding at solid tissue structures and dissolving in lipophilic tissue, the free concentrations of antidepressants in the central nervous system (CNS), and thus receptor occupancy, will be lower because of a time lag of mass transport.

\section{Analysis}

To identify clusters of antidepressants with a similar binding profile, hierarchical cluster analysis was used. This method classifies antidepressants and receptors in clusters in accordance with their overall homology, based on receptor 
occupancy, to yield a binary dendrogram (Fig. 1). Antidepressants were progressively fused into subclusters and clusters until they comprised a single group. The length of the bars between the pair of drugs reflect their dissimilarity that is, the shorter the distance, the more closely related the pair of drugs or receptors. Within the dendrogram a heatmap was integrated. A heatmap is a graphical representation of data in a two-dimensional map where the receptor occupancy values are represented by a spectrum of colors ranging from yellow $(0 \%$ receptor occupancy) till black $(100 \%$ receptor occupancy).

In addition, principle component analysis (PCA) was used as a data reduction technique to find structure in a data matrix of antidepressants versus receptor occupancy for different receptor types. PCA reduces the original set of variables into a smaller, orthogonal set of variables that is composed of linear combinations of receptor occupancy data for particular receptors, called principle components. The coordinates of the orthogonal variable set are chosen such that they capture as much of the total variance as possible in the original data. In this way, it is possible to identify groups of antidepressants that show similar binding profiles. The score plot displays the contribution of each receptor type as a function of the principle components. The loading plot displays the projection of the receptor occupancy data of antidepressants upon the principle components (Fig. 2). The correlation matrix was used in the PCA and transformation was achieved by making use of eigen vectors.

Radar plots were used as a non-statistical method to visualize symmetry or un-symmetry between pharmacological profiles of antidepressants. A radar plot can be thought of as a histogram for an individual antidepressant that has been bent into a circle with each individual spoke representing receptor occupancy for a particular receptor.

Hierarchical cluster analysis and PCA were performed with SPSS $^{\circledR}$ version 12.0. The heatmap was build with Heatmap Builder ${ }^{\circledR}$ version 1.0. Radar plots were constructed in Microsoft Excel ${ }^{\mathbb{B}} 2003$.

\section{RESULTS}

Inhibitory constants and receptor occupancy of 20 antidepressants for 6 binding sites (5-HT reuptake transporter, norepinephrine reuptake transporter, muscarine $\mathrm{M}_{3}$ receptor, histamine $\mathrm{H}_{1}$-receptor, alpha $\alpha_{1}$-receptor and $5-\mathrm{HT}_{2 \mathrm{c}}{ }^{-}$ receptor) were determined and summarized in respectively Tables $\mathbf{1}$ and $\mathbf{2}$.

Fig. (1) shows the dendrogram from the hierarchical cluster analysis with the heatmap integrated. A column within the heat map can be viewed as a pharmacological barcode for a single antidepressant. By comparing these barcodes clusters of antidepressants with similar binding profiles can be identified. Looking at the dendrogram, the most striking differentiation between antidepressants is at the first two nodes, which yields four clusters of antidepressants.

Application of PCA to the receptor occupancy data reveals that $83.4 \%$ can be accounted for by two axes: component 1 and component 2 . This means that a reduction of dimensionality from six receptors to two axes preserves almost the entire variance of the data. The majority of the variance
$(63.3 \%)$ can be attributed to principle component 1 which is highly positive correlated to receptor binding to the norepinephrine reuptake transporter, muscarine $\mathrm{M}_{3}$ receptor, histamine $\mathrm{H}_{1}$-receptor, alpha $\alpha_{1}$-receptor and 5 - $\mathrm{HT}_{2 \mathrm{c}}$-receptor. Component 2 accounts for $20.1 \%$ of variance and is highly positive correlated to receptor binding to the 5-HT reuptake transporter. Fig. (2) shows the score plot and the loading plot. The score plot involves the projection of the antidepressants onto the two components. Antidepressants with similar binding are located in the same area of the score plot. PCA identifies the same four clusters as hierarchical cluster analysis. The loading plot visualizes the contribution of each receptor to the two principle components by vectors.

Radar plots (Fig. 3) complement the dendrogram, heatmap and score plot in visualizing symmetry or un-symmetry between binding profiles in the four clusters of antidepressants in a non-statistical way.

The first cluster comprises sertraline, fluvoxamine, escitalopram, paroxetine, venlafaxine, fluoxetine, citalopram, duloxetine and clomipramine, which all show high affinity for the 5-HT reuptake transporter. Duloxetine and clomipramine show high affinity for the 5-HT reuptake transporter but also had little affinity for one or more other binding sites. The second cluster comprises imipramine, amitriptyline and doxepin. These antidepressants had in common that they show high affinity for all six binding sites. The third cluster comprises maprotiline, nortriptyline, mianserin and mirtazapine which all show high affinity for the histamine $\mathrm{H}_{1}$-receptor and $5-\mathrm{HT}_{2 \mathrm{c}^{-}}$ receptor and less affinity for the 5-HT reuptake transporter. Except mirtazapine, the other antidepressants also show high affinity for the norepinephrine reuptake transporter and moderate affinity for the alpha $\alpha_{1}$-receptor.

The fourth cluster comprised trazodone, nefazodone (withdrawn from the market in 2003), reboxetine and bupropion. These antidepressants were identified as a rest group with no specific similarities within and outside the cluster.

\section{DISCUSSION}

For a better understanding of receptor-mediated pharmacological action we constructed a model to classify antidepressants on the basis of their binding properties of most common transporter- and receptor sites. We used the receptor occupancy model and analyzed it with hierarchical cluster analysis and PCA. Both multivariate techniques were complemented with radar plots to visualize symmetry or nonsymmetry between binding profiles of antidepressants. All methods showed three different clusters of antidepressants with similar properties and a rest group with no specific similarities.

This model deals with several assumptions and restrictions. First, we did not account for the degree of passage of the blood brain barrier of antidepressants. Central nervous system (CNS) concentrations will be lower than peripheral plasma concentrations. Second, the ability of a drug to produce a physiological effect is dependent on receptor occupancy and the propensity of the drug to activate the receptor (intrinsic activity). Drugs bound to a receptor differ in their ability to initiate a change in receptor conformation and physiologic activity. In our model, we assumed that all anti- 
Table 1. Pharmacokinetic Parameters, Inhibitory Constants of Antidepressants

\begin{tabular}{|c|c|c|c|c|c|c|c|c|c|}
\hline \multirow[b]{2}{*}{ Antidepressant } & \multicolumn{3}{|c|}{ Pharmacokinetic Parameters } & \multicolumn{6}{|c|}{$\mathbf{K}_{\mathbf{i}}($ in $\mathbf{n M})$} \\
\hline & $\underset{(\mathbf{n M})}{\mathbf{C}_{\mathrm{ss}}}$ & $\begin{array}{c}\mathbf{f}_{u} \\
(\%)\end{array}$ & $\underset{(\mathbf{n M})}{\mathbf{C}_{\mathrm{u}}}$ & $\begin{array}{c}\text { 5-HT- } \\
\text { Transporter }\end{array}$ & $\begin{array}{l}\text { Norepinephrine } \\
\text { Transporter }\end{array}$ & $\begin{array}{l}5-\mathrm{HT}_{2 \mathrm{C}^{-}} \\
\text {Receptor }\end{array}$ & $\underset{\text { Receptor }}{\text { Muscarine } \mathbf{M}_{3}}$ & $\begin{array}{l}\text { Alpha } \alpha_{1} \\
\text { Receptor }\end{array}$ & $\begin{array}{c}\text { Histamine } \mathrm{H}_{1} \\
\text { Receptor }\end{array}$ \\
\hline amitriptyline & 450.61 & 10.00 & 45.06 & 22.71 & 46.46 & $4.30^{1}$ & 25.90 & 14.20 & 0.81 \\
\hline bupropion & 546.71 & 13.00 & 71.07 & 9550.00 & 10000.00 & $10000.00^{2}$ & 10000.00 & 4200.00 & 10000.00 \\
\hline citalopram & 385.33 & 20.00 & 77.07 & 5.40 & 7089.00 & 617.00 & $1430.00^{4}$ & 5600.00 & $283.00^{1}$ \\
\hline clomipramine & 284.66 & 2.00 & 5.69 & 0.21 & 45.85 & 43.30 & $34.00^{1,3}$ & 3.20 & $47.00^{1}$ \\
\hline doxepin & 554.15 & 25.00 & 138.54 & 68.00 & 29.50 & $8.80^{1}$ & 52.00 & 23.50 & 0.27 \\
\hline duloxetine & 39.53 & 4.00 & 1.58 & 1.23 & 8.72 & 916.00 & $3000.00^{4}$ & 8300.00 & 2300.00 \\
\hline escitalopram & 132.85 & 20.00 & 26.57 & 1.80 & 7177.00 & $2531.00^{1}$ & $1242.00^{4}$ & 3870.00 & 1973.00 \\
\hline fluoxetine & 867.55 & 5.50 & 47.72 & 5.92 & 600.00 & 194.00 & 1000.00 & 2775.00 & 2683.00 \\
\hline fluvoxamine & 345.30 & 23.00 & 79.42 & 6.22 & 2307.00 & $6245.00^{1}$ & $10000.00^{4}$ & 1288.00 & 10000.00 \\
\hline imipramine & 347.72 & 15.00 & 52.16 & 8.37 & 83.00 & $94.00^{1}$ & 60.00 & 32.00 & 26.50 \\
\hline maprotiline & 766.04 & 10.00 & 76.60 & 5800.00 & 11.10 & $122.00^{1}$ & $600.00^{3}$ & 90.00 & 0.79 \\
\hline mianserin & 149.60 & 10.00 & 14.96 & 4000.00 & 11.10 & 3.56 & $501.00^{1}$ & $58.10^{1}$ & 1.03 \\
\hline mirtazapine & 226.07 & 15.00 & 33.91 & 10000.00 & 4600.00 & 39.00 & $800.00^{4}$ & $676.30^{1}$ & 1.60 \\
\hline nefazodone & 1776.90 & 1.00 & 17.77 & 403.00 & 564.00 & $26.00^{2}$ & $10000.00^{4}$ & 26.75 & 10000.00 \\
\hline nortriptyline & 375.25 & 8.00 & 30.02 & 129.40 & 7.39 & $41.00^{2}$ & 50.00 & 55.00 & 7.35 \\
\hline paroxetine & 129.02 & 5.00 & 6.45 & 0.29 & 130.80 & 10000.00 & 80.00 & 2779.00 & 10000.00 \\
\hline reboxetine & 415.65 & 3.00 & 12.47 & 273.50 & 13.40 & 457.00 & $3900.00^{1,4}$ & 10000.00 & 1400.00 \\
\hline sertraline & 510.65 & 2.00 & 10.21 & 1.36 & 884.00 & $1649.00^{1}$ & 1300.00 & 201.00 & 10000.00 \\
\hline trazodone & 342.89 & 8.00 & 27.43 & 367.00 & 10000.00 & $208.40^{2}$ & 10000.00 & 27.00 & 1100.00 \\
\hline venlafaxine & 477.86 & 73.00 & 348.84 & 63.90 & 2448.00 & $2004.00^{1}$ & 10000.00 & 10000.00 & 10000.00 \\
\hline Mean ste & tate plasm & oncentra & & & & & & & \\
\hline & & & & & & & & & \\
\hline : Mean unb & Ind plasma & centrati & & & & & & & \\
\hline : 5-hydroxy & yptamine & & & & & & & & \\
\hline No Ki- or & d-data with & nan rece & rs available & i taken from $b$ & g study with ani & eceptors & & & \\
\hline : No Ki- or & d-data on 5- & $2 \mathrm{c}$-recep & available; & taken from bind & g study with 5-HT-re & & & & \\
\hline : No Ki- or & d-data on $\mathrm{M}$ & ceptor a & lable; Ki ta & en from binding $\mathrm{s}$ & dy with M-receptor & & & & \\
\hline - & ata on $\mathrm{I}$ & 1 & $V$ & 1. & with $\mathrm{M}_{1}$-recepto & & & & \\
\hline
\end{tabular}

depressants are full agonists or antagonists for all receptor types. Third, a certain number of receptors are "spare." Spare receptors exist in excess of those required to produce a full effect. The receptor occupancy model does not correct for the existence of spare receptors. Fourth, prolonged treatment with antidepressants results in downregulation of certain receptor sites. This means that in time, the same receptor occupancy may exert a different response because the number of receptor sites has changed. Fifth, many antidepressants also have active metabolites with different pharmacological binding profiles. $\mathrm{K}_{\mathrm{i}}$-data of the metabolites unfortunately are less well documented than the parent compound. Therefore, it was not possible to include the metabolites in the PCA-model and visualize the binding profiles in radar plots. We summarized the effects of antidepressants on central monoamines in the brain based on a literature review in table 3 to give further insights into the pharmacological properties of the major active metabolites of antidepressants $[13,14,16-20,22,25,26,29,31,32,43-45]$. From these data two metabolites are pharmacologically different from the mother compound. These are N-desmethylclomipramine (metabolite of clomipramine) and nortriptyline (metabolite of amitriptyline). Both metabolites bind more specifically to the NE reuptake transporter than the 5-HT reuptake transporter. The metabolite nortriptyline, also available as a mother compound included in the multivariate model, is a cluster 3 antidepressant (with common affinity for norepinephrine reuptake transporter, $\mathrm{H}_{1}$-receptor and $5-\mathrm{HT}_{2 \mathrm{c}^{-}}$ receptor) but its mother compound, amitriptyline, is categorized in cluster 2 (with high affinity for all receptors investigated). Sixth, our model was limited to the most common transporters and receptors of antidepressants for simplification. In addition to the $5-\mathrm{HT}_{2 \mathrm{C}}$-receptor the $5-\mathrm{HT}_{2 \mathrm{~A}}$-receptor is also associated with side effects of antidepressants. Because the $5-\mathrm{HT}_{2 \mathrm{C}}$-receptor and the $5-\mathrm{HT}_{2 \mathrm{~A}}$-receptor are subtypes of the same receptor we did not expect many differences in receptor occupancy of antidepressants for these receptor subtypes. To confirm this expectation we performed analysis with the 5- $\mathrm{HT}_{2 \mathrm{~A}}$-receptor in the model. The overall classification in four clusters did not change. Furthermore, 
Table 2. Receptor Occupancy of Antidepressants at Mean Steady State Plasma Concentration

\begin{tabular}{|c|c|c|c|c|c|c|}
\hline amitriptyline & 66.49 & 49.24 & 91.29 & 63.50 & 76.04 & 98.23 \\
\hline bupropion & 0.74 & 0.71 & 0.71 & 0.71 & 1.66 & 0.71 \\
\hline citalopram & 93.45 & 1.08 & 11.10 & 5.11 & 1.36 & 21.40 \\
\hline doxepin & 67.08 & 82.44 & 94.03 & 72.71 & 85.50 & 99.81 \\
\hline duloxetine & 56.25 & 15.35 & 0.17 & 0.05 & 0.02 & 0.07 \\
\hline escitalopram & 93.66 & 0.37 & 1.04 & 2.09 & 0.68 & 1.33 \\
\hline fluoxetine & 88.96 & 7.37 & 19.74 & 4.55 & 1.69 & 1.75 \\
\hline fluvoxamine & 92.74 & 3.33 & 1.35 & 0.79 & 5.81 & 0.79 \\
\hline mirtazapine & 0.34 & 0.73 & 46.51 & 4.07 & 4.77 & 95.49 \\
\hline nefazodone & 4.22 & 3.05 & 40.60 & 0.18 & 39.91 & 0.18 \\
\hline nortriptyline & 18.83 & 80.25 & 42.27 & 37.52 & 35.31 & 80.33 \\
\hline paroxetine & 95.70 & 4.70 & 0.06 & 7.46 & 0.23 & 0.06 \\
\hline reboxetine & 4.36 & 48.20 & 2.66 & 0.32 & 0.12 & 0.88 \\
\hline sertraline & 88.25 & 1.14 & 0.62 & 0.78 & 4.84 & 0.10 \\
\hline trazodone & 6.95 & 0.27 & 11.63 & 0.27 & 50.40 & 2.43 \\
\hline venlafaxine & 84.52 & 12.47 & 14.83 & 3.37 & 3.37 & 3.37 \\
\hline
\end{tabular}

5-HT :5-hydroxytryptamine.

Note: all antidepressants are agonists for the 5-HT-transporter and NE-transporter and antagonists for the 5- $\mathrm{HT}_{2 \mathrm{C}^{-}}, \mathrm{M}_{3^{-}}, \alpha_{1^{-}}$and $\mathrm{H}_{1^{-}}$-receptor except fluoxetine, which is a agonist for the $5-\mathrm{HT}_{2 \mathrm{C}}$-receptor.
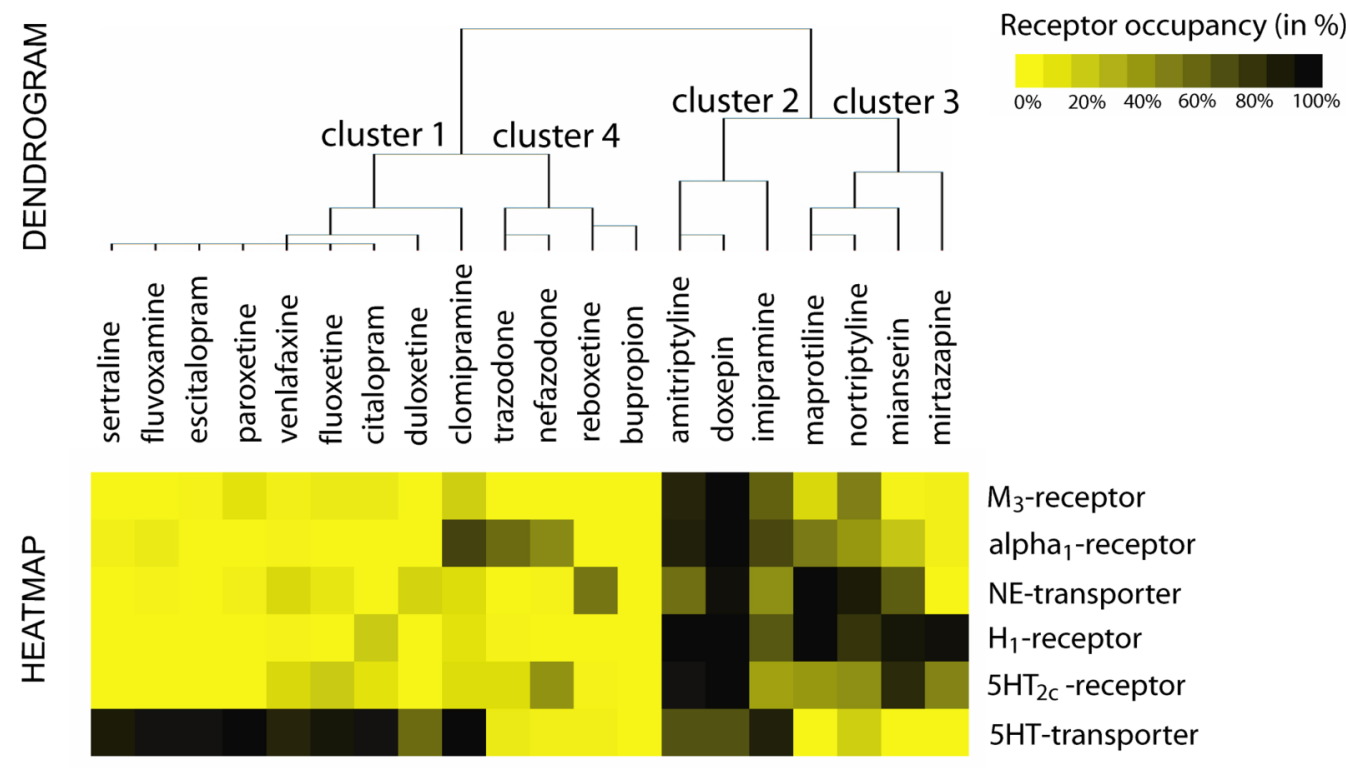

Fig. (1). Dendrogram of hierarchical cluster analysis and heatmap of 20 antidepressants for 2 transporters and 4 receptors. The length of the bars between the pair of drugs in the dendrogram is inversely proportional to the overall homology of the antidepressants. That is, antidepressants situated adjacently present very similar binding profiles, whereas those widely separated show substantially different binding profiles. The heatmap represents the data in a two-dimensional map where the receptor occupancy values are represented by a spectrum of colors ranging from yellow ( $0 \%$ receptor occupancy) till black ( $100 \%$ receptor occupancy). A column within the heat map can be viewed as a pharmacological barcode for a single antidepressant. Antidepressants within the same clusters show practically the same pharmaceutical barcodes. 


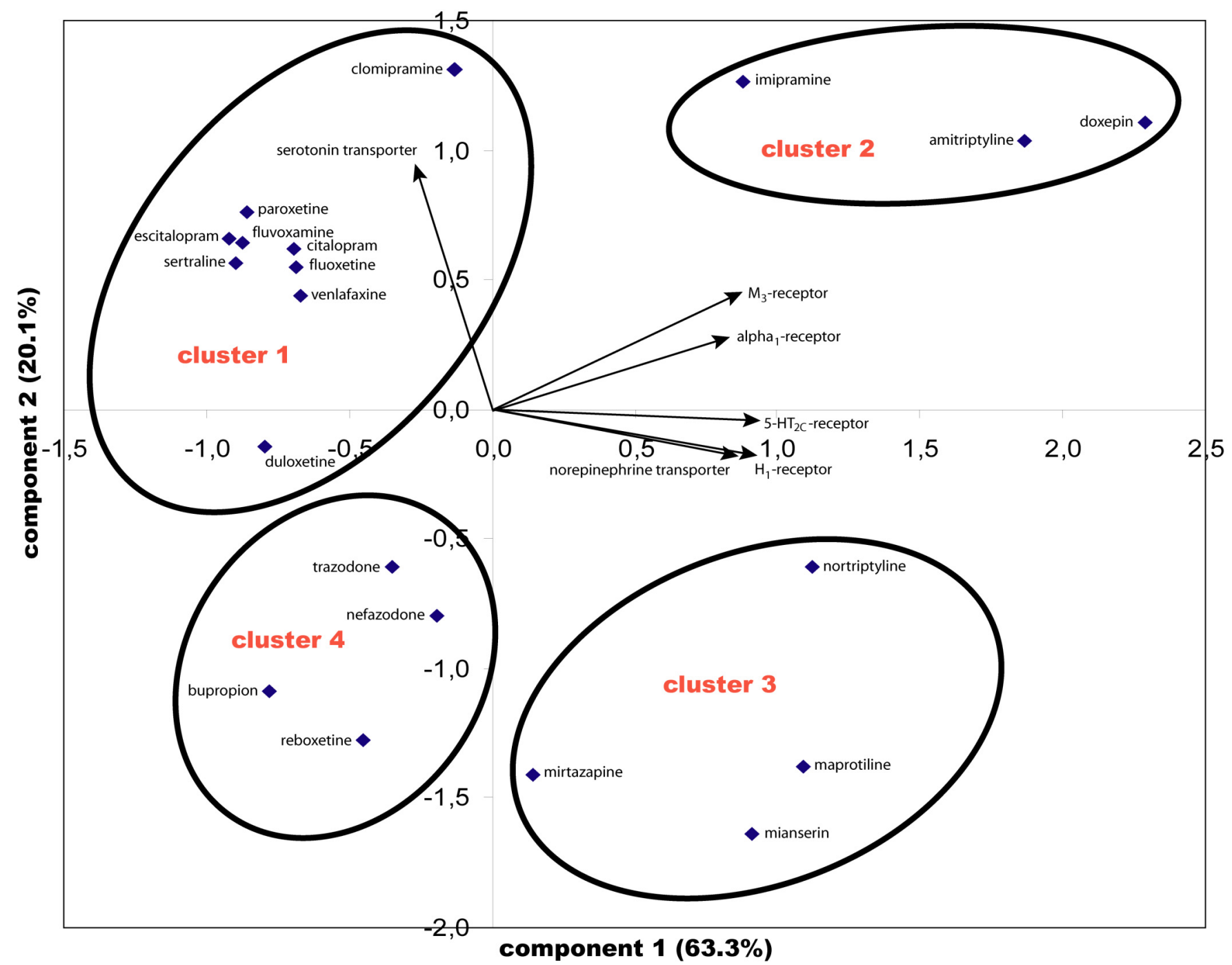

Fig. (2). Score plot and loading plot of PCA analysis of 20 antidepressants for 2 transporters and 4 receptors. The horizontal axis is the first principle component, which explains $63.3 \%$ of the variance in the data matrix, and the vertical axis is the second principle component, which explains $20.1 \%$ of the total variance in the data matrix. The vectors within the score plot display the contribution of each receptor type as a function of the principle components. Drugs are shown in the loading plot as blue diamonds. The circles encompass the same 4 clusters which were identified from hierarchical cluster analysis.

bupropion mainly acts by dopamine reuptake inhibition. We performed additional analysis with the dopamine reuptake transporter included in the model. This did not change the overall classification in four clusters. Finally, it is important to note that mianserin and mirtazapine both have alpha-2 receptor blocking actions and indirectly stimulate the reuptake of norepinephrine. Unfortunately, $\mathrm{K}_{\mathrm{i}}$-data of the alpha-2 receptor for all antidepressants were not complete. Therefore, it was not possible to perform additional analyses with the alpha-2 receptor in the model.

We used multivariate techniques to identify groups of antidepressants with similar binding profiles. This technique permits hypothesis-free exploration of similarities and differences as a function of overall binding profiles and has been demonstrated its value earlier in identifying receptor binding profiles with antiparkinson agents [46]. In the latter study, however, modeling was based on $\mathrm{K}_{\mathrm{i}}$-data. Ideally, receptor occupancy should be measured in vivo or ex vivo using the same method. Pharmacodynamic modeling is often based on $\mathrm{K}_{\mathrm{i}}$-data obtained from in vitro studies (which are already available) and is widely recognized. However, comparison of $\mathrm{K}_{\mathrm{i}}$ 's may not provide a proper evaluation of the pharmacological properties of antidepressants in vivo. A more than 100 fold range is not uncommon for the plasma unbound fraction among drugs. To account for in vivo concentrations at the receptor site, we used the receptor occupancy model and calculated the occupancy-values of antidepressants at steady state conditions. It has proven to be a appropriate measure to estimate the pharmacological effects among the drugs with the same mechanism of action [47-49] even if their receptor dissociation constants, clinical dosages, or pharmacokinetic properties are different.

We combined the receptor occupancy model with multivariate statistical techniques like PCA and hierarchical clus- 


\section{Cluster 1}
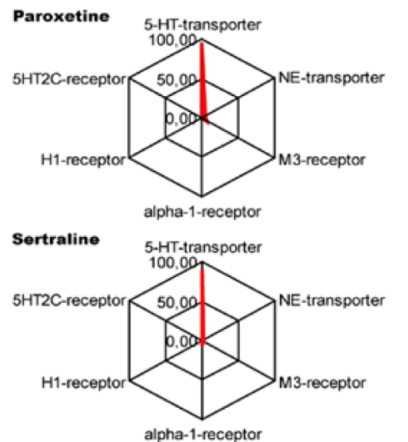

alpha-1-receptor

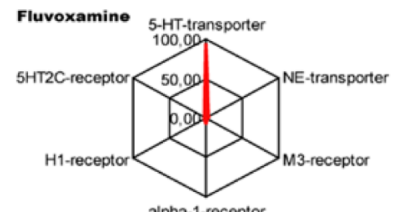

alpha-1-receptor

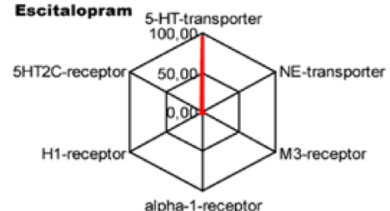

alpha-1-receptor
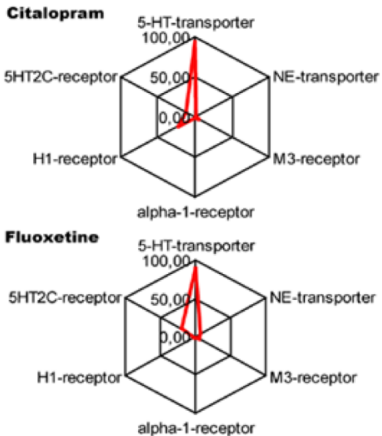

alpha-1-receptor
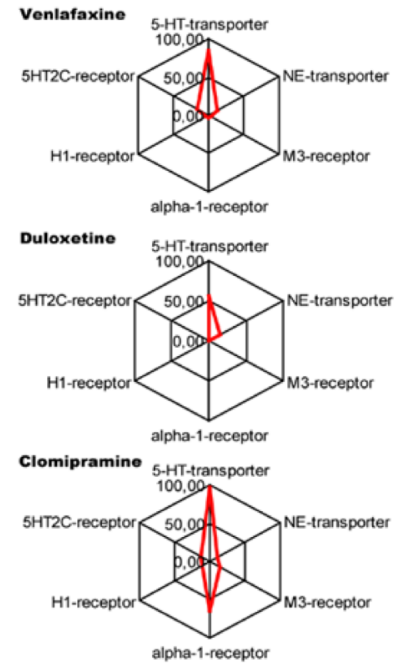

alpha-1-receptor

\section{Cluster 3}

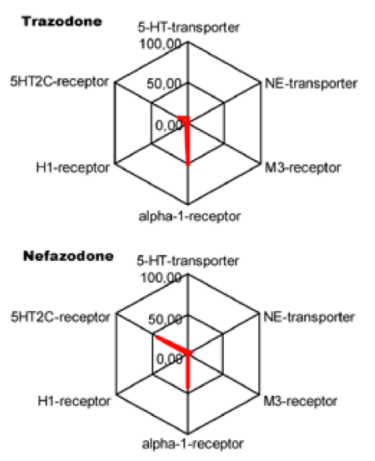

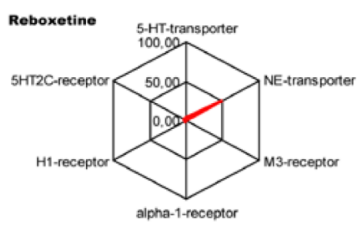

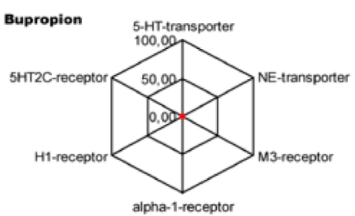

Cluster 2

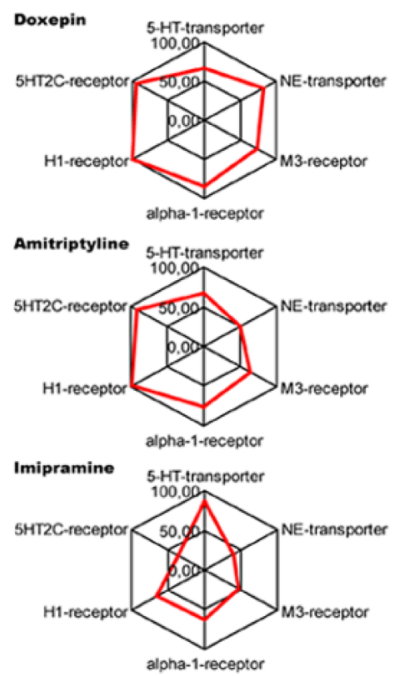

Cluster 4
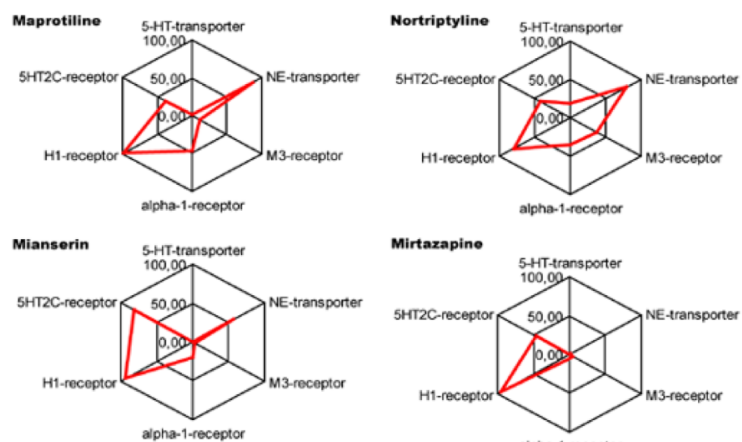

Fig. (3). Radar plots of 20 antidepressants for 2 transporters and 4 receptors. The radar plot is a histogram for an individual antidepressant that has been bent into a circle with each individual spoke representing receptor occupancy for a particular receptor. The greater the distance from the central node of the radar plot, the higher the receptor occupancy for a specific binding site. The radar plots are categorized in the same 4 clusters which were identified from hierarchical cluster analysis. Antidepressants within the same cluster show very similar binding patterns.

tering. This provides a framework for interpretation of contrasting functional profiles of antidepressants in vivo and may aid in clinical decision making. For example, if an antidepressant from one cluster is not well tolerated by a patient due to adverse drug reactions, continuation of therapy may be more successful by switching to an antidepressant from another cluster with different pharmacological properties. This model may also be beneficial in the assessment of safety of novel agents in addition to risk-benefit ratio assessment in clinical trials and would be most appropriately performed before their therapeutic evaluation and post marketing surveillance. Finally, our model also may be used in pharmacovigilance in the search for high risk antidepressants for specific adverse drugs reactions. The pharmacological profile may help us to unravel the mechanism behind these adverse drug reactions. The model and the potential applications have to be validated by additional studies to prove its benefit. Finally, this strategy could also be applied to other groups of psychotropic drugs such as antipsychotics. 
Table 3. Metabolite Activity of Antidepressants

\begin{tabular}{|c|c|c|c|c|}
\hline Antidepressant & $\mathbf{t}_{1 / 2}$ (in hr) & Metabolite & $\mathbf{t}_{1 / 2}$ (in hr) & Activity \\
\hline Amitriptyline & $12-25$ & nortriptyline & $22-88$ & $\begin{array}{l}\text { Amitriptyline is a strong inhibitor of both the } 5 \text {-HT and norepinephrine } \\
\text { transporter. Nortriptyline is preferentially a strong inhibitor of the norepi- } \\
\text { nephrine transporter. Nortriptyline has a longer half-life than amitriptyline } \\
\text { and will significantly contribute to the therapeutic effect of amitriptyline. }\end{array}$ \\
\hline Bupropion & $15-22$ & hydroxybupropion & 20 & $\begin{array}{l}\text { Bupropion is a weak inhibitor of the dopamine transporter and hydroxy- } \\
\text { bupropion is a weak inhibitor of the norepinephrine transporter. The } \\
\text { mechanisms of action responsible for the clinical effects of bupropion are } \\
\text { not fully understood but it has been suggested that both dopaminergic and } \\
\text { noradrenergic components play a role and based on animal models the } \\
\text { hydroxymetabolite contributes significantly to the antidepressant acitivity } \\
\text { of bupropion. }\end{array}$ \\
\hline Clomipramine & 21 & N-desmethylclomipramine & 36 & $\begin{array}{l}\text { Clomipramine is a strong inhibitor of the } 5 \text {-HT transporter and also the } \\
\text { most selective among the tricyclic antidepressants. Desmethylclomi- } \\
\text { pramine on the other hand is a more potent and selective norepinephrine } \\
\text { inhibitor. The half-life of desmethylclomipramine is longer than that of } \\
\text { clomipramine and plays an important role for the therapeutic effect of } \\
\text { clomipramine. }\end{array}$ \\
\hline Fluoxetine & 1-3 days & $\begin{array}{l}\text { N-desmethylfluoxetine } \\
\text { (=norfluoxetine) }\end{array}$ & $\begin{array}{l}7-15 \\
\text { days }\end{array}$ & $\begin{array}{l}\text { Fluoxetine is a strong inhibitor of the 5-HT transporter but also has weak } \\
\text { affinity for the norepinephrine transporter. N-desmethylfluoxetine is also a } \\
\text { strong inhibitor of the 5-HT transporter and more selective than fluoxet- } \\
\text { ine. In addition, N-desmethylfluoxetine has a extremely long half life } \\
\text { compared to fluoxetine and plays an important role for the therapeutic } \\
\text { effect of fluoxetine. }\end{array}$ \\
\hline Imipramine & 24 & $\begin{array}{l}\text { N-desmethylimipramine } \\
\text { (=desipramine) }\end{array}$ & 21 & $\begin{array}{l}\text { Imipramine and N-desmethylimipramine are both strong inhibitors of the } \\
\text { 5-HT and norepinephrine transporter. Imipramine is more selective for the } \\
\text { 5-HT transporter and N-desmethylimipramine more selective for the nore- } \\
\text { pinephrine transporter. }\end{array}$ \\
\hline Sertraline & 24 & $\mathrm{~N}$-desmethylsertraline & $64-104$ & $\begin{array}{l}\text { Sertraline is a strong inhibitor of the } 5-\mathrm{HT} \text { transporter. } \mathrm{N}- \\
\text { desmethylimipramine is a weaker and less selective inhibitor of the 5-HT } \\
\text { transporter but has a longer half-life and therefore might play a role in the } \\
\text { therapeutic effects of sertraline. }\end{array}$ \\
\hline Venlafaxine & 5 & O-desmethylvenlafaxine & 11 & $\begin{array}{l}\text { Venlafaxine and O-desmethylvenlafaxine are both inhibitors of the 5-HT } \\
\text { transporter and the norepinephrine transporter. O-desmethylvenlafaxine } \\
\text { has a longer half-life than venlafaxine and is consequenltly found at higher } \\
\text { plasma concentrations than the parent compound. It therefore is very } \\
\text { likely that O-desmethylvenlafaxine contributes significantly to the thera- } \\
\text { peutic effect. }\end{array}$ \\
\hline
\end{tabular}

\section{SUPPLEMENTARY MATERIAL}

PowerPoint presentation at the $8^{\text {th }}$ Congress of the European Association for Clinical Pharmacology and Therapeutics, 22 August - 1 September 2007, Amsterdam. Visualizing pharmacological activities of antidepressants: a novel approach.

\section{APPENDIX}

Derivation of the receptor occupancy equation:

$\mathrm{C}_{\mathrm{d}}=$ drug concentration around receptor

$\mathrm{C}_{\mathrm{r}}=$ receptor concentration

$\mathrm{C}_{\mathrm{dr}}=$ concentration drug-receptor complex

$\Phi=$ receptor occupancy

The equilibrium reaction equation is:

$\mathrm{C}_{\mathrm{r}}+\mathrm{C}_{\mathrm{d}} \leftrightarrow \mathrm{C}_{\mathrm{dr}}$

Equation 5 represents 2 reactions:

$$
\begin{gathered}
\mathrm{k}_{\mathrm{r}+1}+\mathrm{C}_{\mathrm{d}} \rightarrow \mathrm{C}_{\mathrm{dr}} \\
\mathrm{k}_{-1} \\
\mathrm{C}_{\mathrm{r}}+\mathrm{C}_{\mathrm{d}} \leftarrow \mathrm{C}_{\mathrm{dr}}
\end{gathered}
$$

In steady state conditions the velocities of reactions $5 \mathrm{a}$ and $5 \mathrm{~b}$ are equal:

$\mathrm{C}_{\mathrm{r}} * \mathrm{C}_{\mathrm{d}} * \mathrm{k}_{+1}=\mathrm{C}_{\mathrm{dr}} * \mathrm{k}_{-1}$

Rewriting equation 6 :

$\mathrm{C}_{\mathrm{r}} * \mathrm{C}_{\mathrm{d}} / \mathrm{C}_{\mathrm{dr}}=\mathrm{k}_{-1} / \mathrm{k}_{+1}=\mathrm{K}_{\mathrm{i}}$

$\mathrm{C}_{\mathrm{dr}}=\mathrm{C}_{\mathrm{r}} * \mathrm{C}_{\mathrm{d}} / \mathrm{K}_{\mathrm{i}}$

Receptor occupancy can be expressed as:

$\Phi=\left(\mathrm{C}_{\mathrm{dr}} / \mathrm{C}_{\mathrm{r}}+\mathrm{C}_{\mathrm{dr}}\right) * 100 \%$

Substitution (8) and (9):

$\Phi=\left(\mathrm{C}_{\mathrm{r}} * \mathrm{C}_{\mathrm{d}} / \mathrm{K}_{\mathrm{i}}\right) /\left(\mathrm{C}_{\mathrm{r}}+\left(\mathrm{C}_{\mathrm{r}} * \mathrm{C}_{\mathrm{d}} / \mathrm{K}_{\mathrm{i}}\right)\right) * 100 \%$

Divide numerator and denominator by $\mathrm{C}_{\mathrm{r}}$ :

$\Phi=\left(\left(\mathrm{C}_{\mathrm{d}} / \mathrm{K}_{\mathrm{i}}\right) /\left(1+\left(\mathrm{C}_{\mathrm{d}} / \mathrm{K}_{\mathrm{i}}\right)\right)\right) * 100 \%$

Multiply numerator and denominator by $\mathrm{K}_{\mathrm{i}}$ :

$\Phi=\left(\mathrm{C}_{\mathrm{d}} /\left(\mathrm{K}_{\mathrm{i}}+\mathrm{C}_{\mathrm{d}}\right)\right) * 100 \%$ 


\section{ACKKNOWLEDGEMENTS}

The authors are grateful to S.V. Belitser of the Utrecht Institute for Pharmaceutical Sciences for her skillful assistance with statistical analysis and Prof. Dr. C. Neef for his valuable comments on the pharmacokinetic part of the method section.

\section{REFERENCES}

[1] Reid, I.C.; Stewart, C.A. Br. J. Psychiatry, 2001, 178, 299-303.

[2] Anderson, I.M. Br. Med. Bull., 2001, 57, 161-178.

[3] Anderson, I.M. J. Affect Disord., 2000, 58, 19-36.

[4] Barbui, C.; Hotopf, M.; Amitriptyline, V. Br. J. Psychiat., 2001, 178, 129-144.

[5] Williams, J.W. Jr.; Mulrow, C.D.; Chiquette, E.; Noel, P.H.; Aguilar, C.; Cornell, J. Ann. Intern. Med., 2000, 132, 743-756.

[6] Fava, M. J. Clin. Psychiat., 2000, 61 Suppl 2, 10-12.

[7] Frazer, A. J. Clin. Psychopharmacol., 1997, 17(suppl 1), 2S-18S.

[8] Meyboom, R.H.; Lindquist, M.; Egberts, A.C. Drug Saf., 2000, 22, 415-423.

[9] Krzanowski, W.J. Oxf. Stat l. Sci. Series, 2000, 22, 1-586.

[10] Uges, D.R.A. List of determinations for clinical toxicology and therapeutic drug monitoring, 12 ed.; Laboratory for Clinical and Forensic Toxicology and for Drug analysis. Department of Pharmacy. University Medical Centre Groningen: Groningen, 2006.

[11] Bos, J.M.; Wilhelm, A.J.; Swart, E.L.; Yan-Loenen, A.C.; Touw, D.J. Applied pharmacokinetics; Department Clinical Pharmacology and Pharmacy. Free University Medical Centre, Amsterdam: Amsterdam, 1997.

[12] PDSP-database. http://kidb.cwru.edu/pdsp.php (accessed September 17, 2006) 2006.

[13] Palvimaki, E.P.; Roth, B.L.; Majasuo, H.; Laakso, A.; Kuoppamaki, M.; Syvalahti, E.; Hietala, J. Psychopharmacology (Berl.), 1996, 126, 234-240.

[14] Cusack, B.; Nelson, A.; Richelson, E. Psychopharmacol, 1994, 114, 559-565.

[15] Bymaster, F.P.; Nelson, D.L.; DeLapp, N.W.; Falcone, J.F.; Eckols, K.; Truex, L.L.; Foreman, M.M.; Lucaites, V.L.; Calligaro, D.O. Schizophr. Res., 1999, 37, 107-122.

[16] Stanton, T.; Bolden-Watson, C.; Cusack, B.; Richelson, E. Biochem. Pharmacol., 1993, 45, 2352-2354.

[17] Owens, M.J.; Morgan, W.N.; Plott, S.J.; Nemeroff, C.B. J. Pharmacol. Exp. Ther., 1997, 283, 1305-1322.

[18] Kanba, S.; Richelson, E. Brain Res., 1984, 304, 1-7.

[19] Tatsumi, M.; Groshan, K.; Blakely, R.D.; Richelson, E. Eur. J. Pharmacol., 1997, 340, 249-258.

[20] Vaishnavi, S.N.; Nemeroff, C.B.; Plott, S.J.; Rao, S.G.; Kranzler, J.; Owens, M.J. Biol. Psychiat., 2004, 55, 320-322.

[21] Millan, M.J.; Gobert, A.; Lejeune, F.; Newman-Tancredi, A.; Rivet, J.M.; Auclair, A.; Peglion, J.L. J. Pharmacol. Exp. Ther., 2001, 298, 565-580

[22] Toll, L.; Berzetei-Gurske, I.P.; Polgar, W.E.; Brandt, S.R.; Adapa, I.D.; Rodrigez, L.; Schwartz, R.W.; Haggart, D.; O'Brien, A.; White, A.; Kennedy, J.M.; Craymer, K.; Farrington, L.; Auh, J.S. NIDA Res. Monogr., 1998, 178, 440-466.

[23] Booth, R.G.; Moniri, N.H.; Bakker, R.A.; Choksi, N.Y.; Nix, W.B.; Timmerman, H.; Leurs, R. J. Pharmacol. Exp. Ther., 2002, 302, 328-336.

[24] Schotte, A.; Janssen, P.F.; Gommeren, W.; Luyten, W.H.; Van Gompel, P.; Lesage, A.S.; De Loore, K.; Leysen, J.E. Psychopharmacology (Berl.), 1996, 124, 57-73.
[25] Bymaster, F.P.; Katner, J.S.; Nelson, D.L.; Hemrick-Luecke, S.K.; Threlkeld, P.G.; Heiligenstein, J.H.; Morin, S.M.; Gehlert, D.R.; Perry, K.W. Neuropsychopharmacology, 2002, 27, 699-711.

[26] Paczkowski, F.A.; Bryan-Lluka, L.J.; Porzgen, P.; Bruss, M.; Bonisch, H. J. Pharmacol. Exp. Ther., 1999, 290, 761-767.

[27] Owens, J.M.; Knight, D.L.; Nemeroff, C.B. Encephale, 2002, 28 350-355.

[28] Millan, M.J.; Newman-Tancredi, A.; Audinot, V.; Cussac, D.; Lejeune, F.; Nicolas, J.P.; Coge, F.; Galizzi, J.P.; Boutin, J.A.; Rivet, J.M.; Dekeyne, A.; Gobert, A. Synapse, 2000, 35, 79-95.

[29] Bonhaus, D.W.; Weinhardt, K.K.; Taylor, M.; DeSouza, A.; McNeeley, P.M.; Szczepanski, K.; Fontana, D.J.; Trinh, J.; Rocha, C.L.; Dawson, M.W.; Flippin, L.A.; Eglen, R.M. Neuropharmacology, 1997, 36, 621-629.

[30] Knight, A.R.; Misra, A.; Quirk, K.; Benwell, K.; Revell, D.; Kennett, G.; Bickerdike, M. Naunyn Schmiedebergs Arch. Pharmacol., 2004, 370, 114-123.

[31] Sanchez, C.; Hyttel, J. Cell Mol. Neurobiol., 1999, 19, 467-489.

[32] Koch, S.; Hemrick-Luecke, S.K.; Thompson, L.K.; Evans, D.C.; Threlkeld, P.G.; Nelson, D.L.; Perry, K.W.; Bymaster, F.P. Neuropharmacology, 2003, 45, 935-944.

[33] Bymaster, F.P.; Dreshfield-Ahmad, L.J.; Threlkeld, P.G.; Shaw, J.L.; Thompson, L.; Nelson, D.L.; Hemrick-Luecke, S.K.; Wong, D.T. Neuropsychopharmacology, 2001, 25, 871-880.

[34] Kuo, F.; Gillespie, T.A.; Kulanthaivel, P.; Lantz, R.J.; Ma, T.W.; Nelson, D.L.; Threlkeld, P.G.; Wheeler, W.J.; Yi, P.; Zmijewski, M. Bioorg. Med. Chem. Lett., 2004, 14, 3481-3486.

[35] Bonhaus, D.W.; Bach, C.; DeSouza, A.; Salazar, F.H.; Matsuoka, B.D.; Zuppan, P.; Chan, H.W.; Eglen, R.M. Br. J. Pharmacol. 1995, 115, 622-628.

[36] Fernandez, J.; Alonso, J.M.; Andres, J.I.; Cid, J.M.; Diaz, A.; Iturrino, L.; Gil, P.; Megens, A.; Sipido, V.K.; Trabanco, A.A. J. Med. Chem., 2005, 48, 1709-1712.

[37] Cussac, D.; Newman-Tancredi, A.; Quentric, Y.; Carpentier, N.; Poissonnet, G.; Parmentier, J.G.; Goldstein, S.; Millan, M.J. Arch. Pharmacol., 2002, 365, 242-252.

[38] Wainscott, D.B.; Sasso, D.A.; Kursar, J.D.; Baez, M.; Lucaites, V.L.; Nelson, D.L. Naunyn Schmiedebergs Arch. Pharmacol. 1998, 357, 17-24.

[39] Grandy, D.K.; Marchionni, M.A.; Makam, H.; Stofko, R.E.; Alfano, M.; Frothingham, L.; Fischer, J.B.; Burke-Howie, K.J.; Bunzow, J.R.; Server, A.C.; et al. Proc. Natl. Acad. Sci. USA, 1989, 86, 9762-9766.

[40] de Boer, T.H.; Maura, G.; Raiteri, .M.; de Vos, C.J.; Wieringa, J.; Pinder, R.M. Neuropharmacology, 1988, 27, 399-408.

[41] Wikstrom, H.V.; Mensonides-Harsema, M.M.; Cremers, T.I; Moltzen, E.K.; Arnt, J. J. Med. Chem., 2002, 45, 3280-3285.

[42] Bourin, M. ; Chue, P. ; Guillon, Y. CNS Drug Rev., 2001, 7, 25-47.

[43] Ghoneim, O.M.; Legere, J.A.; Golbraikh, A.; Tropsha, A.; Booth, R.G. Bioorg. Med. Chem., 2006, 14, 6640-6658.

[44] Martin, P.; Massol, J.; Colin, J.N.; Lacomblez, L.; Puech, A.J. Pharmacopsychiatry, 1990, 23, 187-194.

[45] Muth, E.A.; Haskins, J.T.; Moyer, J.A.; Husbands, G.E.; Nielsen, S.T.; Sigg, E.B. Biochem. Pharmacol., 1986, 35, 4493-4497.

[46] Millan, M.J.; Maiofiss, L.; Cussac, D.; Audinot, V.; Boutin, J.A.; Newman-Tancredi, A. J. Pharmacol. Exp. Ther., 2002, 303, 791804.

[47] Ito, K.; Ohtani, H.; Sawada, Y. Br. J. Clin. Pharmacol., 2007, 63(4), 394-403.

[48] Yamada, Y.; Takayanagi, R.; Tsuchiya, K.; Ito, K.; Ohtani, H.; Sawada, Y.; Iga, T. J. Ocul. Pharmacol. Ther., 2001, 17, 235-248.

[49] Sawada, Y.; Yamada, Y.; Iga, T. Yakugaku Zasshi, 1997, 117, 6590

This is an open access article distributed under the terms of the Creative Commons Attribution License (http://creativecommons.org/licenses/by/2.5/), which permits unrestrictive use, distribution, and reproduction in any medium, provided the original work is properly cited. 